\title{
Toxicity of parasites and their unconventional use in medicine
}

\author{
Grzegorz Król' ${ }^{1, A, C-D \oplus}$, Agnieszka Tomaszewska ${ }^{2, D \oplus}$, Grzegorz Wróbel $^{3, B-C \oplus}$, Paulina Paprocka ${ }^{1, C \oplus}$, \\ Bonita Durnaśs ${ }^{1, E-F} \oplus$, Ewelina Piktel ${ }^{4, C-D} \oplus$, Robert Bucki ${ }^{1, E-F} \oplus$ \\ 1 Department of Microbiology and Immunology, Institute of Medical Sciences, Faculty of Medicine and Health Sciences, \\ Jan Kochanowski University in Kielce, Kielce, Poland \\ ${ }^{2}$ The Professor Edward Lipinski School of Economics, Law and Medical Sciences in Kielce, Kielce, Poland \\ ${ }^{3}$ Department of Anatomy, Institute of Medical Sciences, Faculty of Medicine and Health Sciences, Jan Kochanowski \\ University, Kielce, Poland \\ ${ }^{4}$ Department of Medical Microbiology and Nanobiomedical Engineering, Medical University of Bialystok, Bialystok, Poland \\ A - Research concept and design, B - Collection and/or assembly of data, C - Data analysis and interpretation, \\ $D$ - Writing the article, $E$ - Critical revision of the article, $F$ - Final approval of article
}

Król G, Tomaszewska A, Wróbel G, Paprocka P, Durnaś B, Piktel E, Bucki R. Toxicity of parasites and their unconventional use in medicine. Ann Agric Environ Med. 2019; 26(4): 523-531. doi: 10.26444/aaem/109665

\begin{abstract}
Introduction. Over 300 species of parasites can possibly be passed on humans. Most of the parasitic infections are defined based on their pathogenicity; however, some positive effects of a parasite existence within the human body have recently been suggested. Beneficial outcomes of parasite infections might result from the production and release of metabolites, modification of host immune response or products uptake of the host.

Objective. The aim of the study was a comprehensive analysis of a wide range of effects of parasites on the human body, including an overview of the toxic and positive effects.

State of knowledge. In the light of the latest research presenting the unconventional use of parasites in medicine, the widely understood of their impact on the human body can also be considered in a positive context. Clinical cases from diseases caused by the toxic effects of parasites, as described in recent years, indicate that the problem of parasitic infections still persists. Despite a great deal of knowledge about the toxic effects of parasites on the human organism and, above all, despite the improvement in sanitary conditions, there is a resurgence of parasitic infections, as evidenced, e.g. by the examples presented in this review.

Conclusions. The examples of positive effects of parasites presented so far give hope for the future in terms of fighting many diseases for which pharmacological treatment has not yet brought a positive effect. A better understanding of those processes might lead to the development of new methods of unconventional medical treatment.
\end{abstract}

\section{Key words}

parasites, toxicity, helminth therapy

\section{INTRODUCTION}

Parasitism is an antagonistic phenomenon in which the species (parasites) use the source of food and living environment of another species, that can act as an intermediate or definitive host. The basic feature of this phenomenon in medicine is the pathogenicity; however, scientists report increasingly a potential positive influences of a parasite existence within the human body [1]. The discussion on the widely understood effects of parasites on the human organism should start with an analysis of the definition of parasitism itself. This concept is subject to constant changes as natural sciences develop. One of the first definitions describes a parasitic organism in terms of its eating behaviour [2]. According to this category, a parasite is described as an organism that needs another organism in order to live, as a source of food and a place for growth and reproduction [2,3]. Later the definition was supplemented with negative (also toxic) effects of the parasite's activity - the parasite is therefore an organism that

Address for correspondence: Grzegorz Wróbel, Department of Anatomy, Institute of Medical Sciences, Faculty of Medicine and Health Sciences Jan Kochanowski University in Kielce, St. IX Wieków Kielce 19, 25-317, Kielce, Poland E-mail: grzegorz.wrobel@ujk.edu.pl

Received: 25.02.2019; accepted: 25.05.2019; first published: 26.06 .2019 feeds itself at the expense of the host's body, thereby causing harm. Another definition of parasitism was developed by the view that it is a purely ecological concept, representing a parasitic organism that uses other living organisms as a source of food, and transfers to its hosts the necessity to regulate the relationships with the surrounding environment. As biochemical and genetic research developed, the definition of parasitism was further modified, according to which the relationship between the parasite and the host is metabolic - the parasite as an organism dependent on the host to a different metabolic extent. This extent varies between freeliving animals and internal parasites. While in the former case it is $0 \%$, it is $100 \%$ for animals that practice the obligatory type of parasitism. The metabolic dependence is conditioned by such factors on the part of the host as, among others, the type of food the host consumes, its body temperature, and even its biochemical composition (composition of amino acids, proteins, sugars, etc.) [2-6].

The number of parasites that can be passed on to human body can reach over 300 species, which include both parasites occurring on the body surface (external parasites) and those living in the human system (internal parasites). The place of parasite occurrence includes hair, skin, blood, muscles, eye, liver, brain, although most often it can be found in 
the intestines $[7,8]$. The location of the parasites is related with the ways of infection, as the main sources of parasitic infection are contaminated water and food, mostly resulting from lack of personal hygiene, unwashed vegetables/fruits, undercooked/under-fried meat, such as freshwater fish, crustaceans, wild animals or beef [9-15]

It is estimated that two billion people worldwide are infected with at least one parasite species, and three million suffer from parasitosis. According to the literature, health problems resulting from parasitism are affecting populations in developing countries, living in poverty with a dominance of parasitic infections caused by intestinal helminths and protozoan [2]. On the territory of Poland, where a human being can be a host for about 40 species of parasites, this number is lower, but even with a lower amount of pathogenic species the statistical data shows that an invasion of pinworms can reach $95 \%$ of the population, whipworm - $80 \%$ and human roundworm - 50\% [2, 16-19].

The improvement of sanitary conditions in industrialized countries and the effectiveness of parasite control measures reduce the incidence of only some parasites. Prevention and control of parasitic diseases through constant monitoring of the epidemiological situation of these diseases depends, to a large extent, on the effective teaching and training of medical personnel in the field of medical parasitology, awareness of the risks that parasitic organisms may cause, and more effective intervention of supervision and control of sanitaryepidemiological services $[20,21]$.

\section{OBJECTIVE}

The main aims of the study are: a comprehensive analysis of a wide range of effects of parasites on the human body, including an overview of the toxic effects of parasites on the human body, and an analysis of the positive impact of parasites, which currently falls within the scope of unconventional medicine. To fulfill these aims, the electronic medical database PubMed was searched on January 20, 2019 for studies showing a positive effect of parasitic infections on the human body. The following were used as key words: parasites, toxicity, helminth therapy.

\section{STATE OF KNOWLEDGE}

Harmfulness of parasites to the human organism. The negative impact of parasites on the human body can vary, depending on the number and the location of the parasites, as well as the age and physiological condition of the infected person and whether they are intermediate or definitive hosts. Most parasites cause a harmful mechanical impact damaging the skin and tissues [22-24]. External parasites insert their stick and mouth organs into the skin, causing damage, and then use the sources of food such as blood, causing inflammation and itching. They can also release toxic substances within the wound [25]. Parasites living inside the human body also cause mechanical damage to the internal organs through the use of their stick organs, such as suckers, hooks, teeth or daggers. Examples include tapeworms, liver flukes or duodenum hookworm; the latter, apart from pulling living tissue out of the duodenum and feeding on blood, causes haemolysis and damage to erythrocytes [26, 27].
Harmful mechanical effects may result not only from the parasite's sticking to the host tissues, but also from the parasite's migration within the body or the number of parasites. An example of this can be different species of tapeworms or human roundworms, which in excess can lead to the obstruction of the intestinal lumen or the pancreatichepatic duct $[28,29]$. The migration of parasites, such as human roundworm, may cause perforations of the alimentary tract, blood vessels (mainly juvenile forms), as well as damage to the eustachian tube [30]. Pinworms can also become a source of appendicitis, bladder or vagina inflammation during their migration [30]. Negative mechanical effects, to a large extent, depend on the location of the parasite, which may not show very harmful ailments for the host, as well as a strong pathogenic effect [30]. Cysticercosis caused by the armed tapeworm Taenia solium if located in the muscles, until survival of the blackheads shows ailments which are hardly noticeable to humans $[31,32]$. Dead blackheads cause a strong cell reaction. The situation is different when the blackheads are located in the brain or in the eye, causing serious ailments that often lead to disability or death [33-37].

Parasites may also have toxic effects, which in the case of external parasites are often manifested by itching, scabies, allergic conditions, but are also associated with many diseases such as tick-derived diseases or malaria. The toxic effects of internal parasites can cause serious organ disturbances, haemolysis as well as severe allergic reactions. Apart from mechanical or toxic effects, parasites have a negative impact through food competition, depriving the host of important nutrients such as vitamin $\mathrm{B}_{12}$ (teniasis), or in the case of infection with haematophagic parasites (feeding on blood) such as duodenum hookworm [38, 39]. According to reports, the change in normal gastro-intestinal flora by intestinal parasites is associated with diarrhea, the main cause of morbidity and mortality in developing countries [40-44].

Many parasites can also cause pathogenic changes accompanied by clinical symptoms. Pathological changes may occur at the site where the parasite is present, in which case they are referred to as direct local changes [45]. An example of this is the impact of parasites on tissues, which is observed in Trichinella spiralis larvae. The larvae develop in the muscle cells causing loss of the active properties of the muscle [45]. Another example is the species Dioctophyme renale, which occurs in the renal pelvis, resulting in renal parenchyma atrophy $[46,47]$ A species especially dangerous for humans is Entamoeba histolytica, which destroys the mucosa epithelium in the large intestine, leading to water absorption disorders, and is manifested by strong diarrhea [48-51].

Direct pathological changes caused by parasites result in indirect-general changes that occur in the place where the parasite is present. They are caused by factors from the immune system of the host and under the influence of biochemical factors of the parasite [52].

Indirect pathological changes result in a number of clinical symptoms in the host. These include chills, diarrhea, increased body temperature, muscle pain, liver enlargement and cirrhosis [53]. Such symptoms can be observed, inter alia, in the case of Trypanosoma brucei gambiense infection [54].

In particular, parasites of Toxocara type (Toxocara canis, Toxocara leonina), responsible for the clinical symptoms of toxocariasis, are very dangerous to humans [55]. The infection is extremely dangerous because in the initial phase 
the parasites develop asymptomatically in the body. The only symptom is eosinophilia - increased count of one of the types of white blood cells - eosinophils. The disease takes the form of visceral toxocariasis (larvae are found in various internal organs, e.g. the liver), eye toxocariasis (larvae nest in the eye), brain toxocariasis (neurotoxocariasis; larvae are present in the brain), and latent (asymptomatic) toxocariasis. In each of these toxocariasis cases, symptoms depend on the severity of the infection and the location of the larvae in the body [56-59].

The majority of the effects of parasites on the organism result in a weakening of the immune system of the host, which may contribute to its susceptibility to other diseases [60].The immune pathways required for the induction, expansion and maintenance of anti-parasite responses are still under investigation [60]. Considering their immune effects, parasites can act as regulators of the host immune response that inhibit some pathways of immune activation (e.g, DC antigen presentation, T-cell cytokine and B-cell antibody production, and epithelial cell alarmin release), modulating other pathways (e.g, TH cell subset differentiation and B-cell isotype switching), and inducing still others (e.g, Treg and Breg cell differentiation and tolerogenic DC responses) [6163] (Fig. 1). Most parasites have developed strategies to avoid immune elimination. Understanding the correlation between parasitic infections and autoimmune disorders may be helpful in prediction and early identification, and conceivably the prevention of these diseases. Perhaps clarification of the mechanism of immune regulation by parasite infection will contribute greatly to the treatment for inflammatory diseases such as colitis ulcerosa [63-67].
Defensive mechanisms in the parasite-host interactions. The definition of parasitism quoted in the Introduction, which describes a parasite as an organism metabolically dependent on the host, is reflected in analysis of the hostparasite interaction $[68,69]$. The biochemical nature of this dependence makes the process extremely complicated. Therefore, each parasite-host interaction has to be considered individually, depending on the type of parasitic organism [69]. This does not change the fact that from a general point of view the defence reactions in the host-parasite interaction are considered in two directions. The first of these concerns the defensive mechanism of the host in response to the parasitic invasion, while the second is the defence reaction of the parasite against the host [69].

The host's defence reactions are the basis of all immunological processes. The entry of a parasite into the host organism leads to a number of mechanisms being triggered by the immune response. This is a typical reaction of the immune system to the appearance of antigens. Among antigens of parasites orgins (which is the subject here), the most important for the host are those which are either secretions or excretions of the parasite, or antigens that are on the surface. The host's defence reactions are directed to removing the parasite from its body. These interactions are among the most important phenomena that occur in the discussed parasite-host interaction $[63,64]$.

The defensive mechanism of the parasite takes the form of the so-called preventive defence and the so-called active defence. In the first case, the parasite defends itself against being recognized by the immune system of the host. This method of defence by the parasite nvolves, amongst others: immunosuppression, residence inside the host's cells,

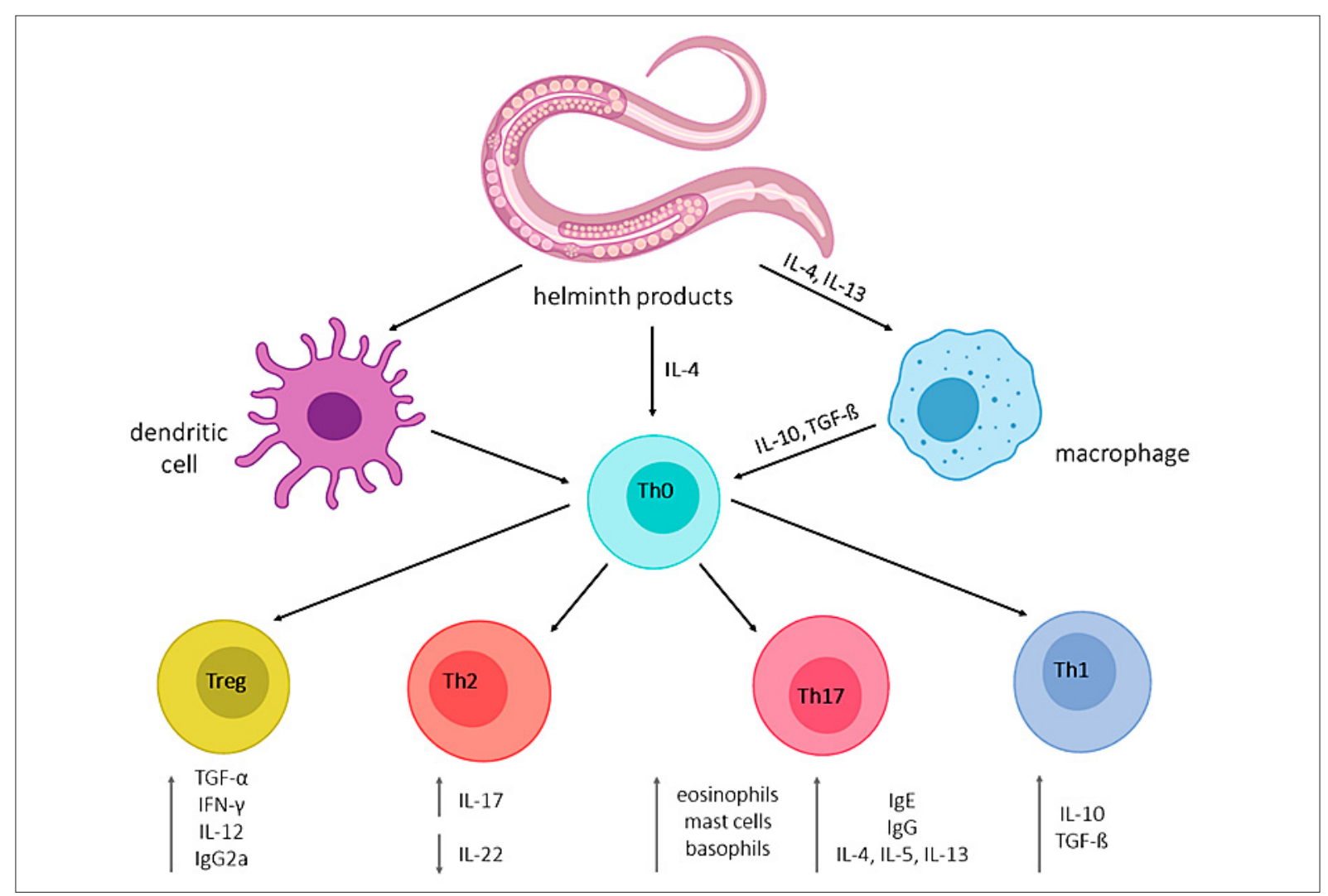

Figure 1. Cytokines profile in parasitic helminth infection. Secretory products of helminth promote the synthesis of pro-inflammatory cytokines and immunomodulatory molecules, which promote helminth parasites expulsion and induction of inflammatory state [137] 
antigenic mimicry, or change in the immunogenicity of its own genes $[69,70]$. The active defence of the parasite is based on the direct defence against the host's immunological reaction [70].

The modification of surface antigens located in the outer membrane is one of the most important parasite's defensive mechanisms. The protein part of the antigen is most often modified by the glycosylation [71].

Another defence mechanism of the parasite is the phenomenon of immunosuppression, which occurs in people infected with Plasmodium. In this case, the production process of antibodies and immune cells is inhibited by some prostaglandins. [72, 73].

The most effective phenomenon in the parasite's defence against the attack of host antibodies is its presence inside the host cells, e.g. inside the erythrocytes that separates the parasite from the molecular machinery of immune response [74]. This form of defence against the host's immunological response is also observed in some nematodes [75]. An example is Trichinella spiralis whose larvae spent some of their life cycle inside the muscle cells [75].

The process of active defence of the parasite is a direct reaction of the host, taking place mainly through fighting antibodies with lytic enzymes. The secretion of lytic enzymes by parasites into host organs mediates critical interactions because of the invasion and destruction of interstitial tissues, enabling parasite migration to other sites within the hosts. Experimental research to-date indicates that as a result of the first contact of the parasite with the host, the parasites launch a number of defensive reactions. The development of the parasite is possible not only through avoiding the defensive mechanisms of the host, but also through keeping it alive for as long as possible because of the obligatory nature of parasitism [48, 76-78].

Use of parasites in medicine. The use of parasites in the therapeutic methods, due to their pathogenicity and the consequences of their existence in the host body, is of great concern. However, the use of some species of parasites in an appropriate way may contribute to beneficial outcomes in some unconventional application, mostly in autoimmune and immunological diseases [79-81]. Hirudynotherapy is an effective method in the natural treatment of many diseases that is currently experiencing a renaissance. For treatment, leeches derived exclusively from laboratory cultures, are used. These are all leeches belonging to the Hirudo medicinalis species, i.e. Hirudo medicinalis officinalis, Hirudo medicinalis medicinalis and Hirudo medicinalis orientalis [82, 83]. The broad spectrum of medical use of these organisms includes the treatment of many diseases, such as: cardiovascular diseases, thromboembolism, coronary diseases, diseases of the endocrine, gastrointestinal, urogenital, respiratory and osteoarticular systems. The substances that are part of the secretion of the salivary glands of these organisms have the therapeutic effect of medicinal leeches. Among these substances, blood coagulation inhibitors, hirudin and antistasis (Table 1) are a priority. These include substances that inhibit platelet aggregation: apyrase, saratine, viburnum, as well as proteinase inhibitors with anti-inflammatory activity and agents that inhibit the growth of microorganisms, such as chloromycetin, hyaluronidase, collagenase [84-87]. Studies confirming the positive effect of salivary secretion of leeches on the nervous system are of particular interest. It is associated with the release by Hirudo medicinalis endorphins and neurotransmitters, such as dopamine, serotonin, acetylcholine or histamine, which are essential for the proper functioning of the nervous system [89]. Recent discoveries concern the occurrence of enzymes and inhibitors in the salivary secretion causing the growth of sensory neurons in the ganglia, which opens the possibility of using hirudynotheraphy for the treatment of Parkinson's and Alzheimer's diseases (Table 1) [89, 90].

In developing countries, an inverse relationship between helminthic diseases and allergic diseases has been observed in relation to industrialized countries $[91,92]$. According to the literature, in Ecuador [93], Gabon [94] and Brazil [95], parasite infections have been shown to have a protective effect against allergic reactivity. It has also been shown that the risk of atopic skin sensitization increases as a result of the antiviral treatment in such countries as Gabon [94] Venezuela [96] and Vietnam [97]. In 2008, about $37 \%$ of the world's population was infected with helminths, mainly in developing countries; however, helminthiasis is a rarity in industrialized countries [98]. In these environments, it was observed that a higher number of parasitic diseases translated into a lower number of allergic diseases and asthma [91,

Table 1. Effects of active ingredients from Hirudo medicinalis salivary glands in selected diseases

\begin{tabular}{|c|c|c|}
\hline & Active compound & Action \\
\hline \multirow{9}{*}{$\begin{array}{l}\text { Thromboembolic } \\
\text { diseases }\end{array}$} & Hirudine & A strong thrombin inhibitor, prevents attacks and strokes more effectively than acetylsalicylic acid \\
\hline & Antistatin & An inhibitor of factor Xa, reduces the formation of blood clots \\
\hline & $\begin{array}{l}\text { Inhibitors of plasma } \\
\text { transglutaminases I and II }\end{array}$ & Inhibitors of fibrin stabilizers, reduce the formation of blood clots \\
\hline & Apyrase & A non-specific inhibitor of thrombocyte aggregation, reduces platelet aggregation \\
\hline & Saratin, viburnum & Proteins that inhibit platelet adhesion to collagen, prevent thrombocyte aggregation \\
\hline & Destabilase & Inhibits platelet aggregation induced by plaque activator and collagen \\
\hline & Haementerin & Plasminogen activator for plasmin, dissolves clots and clears vessels \\
\hline & Haementin & Proteinase breaks down fibrinogen into peptide fragments, dissolves fibrin \\
\hline & Destabilase & Activation of plasminogen, decomposition of endoizopeptides, building stable fibrin \\
\hline \multirow{3}{*}{$\begin{array}{l}\text { Diseases of the } \\
\text { nervous system }\end{array}$} & Endorphins & Happiness hormones, sedation, analgesia \\
\hline & Destabilase & A proteolytic enzyme, stimulation of nerve cell growth In the ganglia (observation of a 10-day-old chicken embryo) \\
\hline & Bdelina A, bdelina B, egins & $\begin{array}{l}\text { Growth of nerve cells to the same extent as nerve growth factor (observation of 10-day-old chicken embryo), high hopes } \\
\text { for the treatment of neurodegenerative disorders, e.g. neuromuscular dystrophy, Parkinson's and Alzheimer's diseases }\end{array}$ \\
\hline
\end{tabular}


99]. According to reports, the reduction of respiratory allergic symptoms in the case of intense infections caused by helminth is an example of the beneficial effect of parasites, although this reduction provides a greater chance of their reproduction and development in the host's body [100-102]. Moreover, in research on mice, inhibition of inflammation, development of autoimmune diabetes and some types of arthritisn were observed [103-106].

The use of parasites, such as nematodes, can have a positive effect on the human immune system. In the case of duodenum hookworm infection, in the mild course of infection which did not show any significant pathogenic changes, such as anaemia, did not affect the functioning of the intestine, and positive effect on allergies, asthma and infectious diseases. Similarly, a positive effect was demonstrated on the prevention of allergies by administering probiotics at an early stage of life, which affected the immune system, diversifying it in a pro-inflammatory, pro-allergic direction. In this direction, parasites can also be used but they themselves can cause allergic states, inflammatory reactions, asthma, and even anaphylactic shock as a result of toxic effects, which outweighs the risk of their application over benefits [107-115].

Another aspect concerns the use of parasites in forensic medicine. In this area, a significant role is played by necrophaga, whose appearance on corpses, as well as the development of larvae, may contribute to determination of the time and circumstances of death of the examined corpses [116]. An interesting use of parasites is forensic entomotoxicology, which investigates the influence of xenobiotics, such as drugs, alcohol, medicines on necrophaga development and their use as a source of biological material of the deceased [117]. Sometimes the causes of death are found in autopsy in which liver damage caused by a parasite, e.g. Echinococcus multilocularis, is discovered. Often, the presence of a parasite can tell us about nursing negligence, poisoning, and the place where the infected person stayed [118].

It is not only in forensic medicine that the use of parasites can be found. In medicine, the larvae of the common green bottle fly - Lucilia sericata, shown to have a beneficial effect in the removal of dead tissue from a wound, and killing the micro-organism [119]. Larvae secrete enzymes (belonging to the group of collagenases having the same effect as trypsin and chymotrypsin) proving effective in the case of some strains of Staphylococcus aureus, including methicillin-resistant A and B streptococcus, and some strains of Pseudomonas. Most often, treatment with larvae is used to treat various types of infections, necrotic wounds, lower limb ulcers, and infected post-operative wounds [120-122].

Recent research shows that parasites have the ability to inhibit the immunological response of their hosts, which allows them to settle down for a long time without causing an inflammatory reaction. Research conducted on a mouse model of multiple sclerosis has shown that treatment with parasites may bring some benefits to patients suffering from this disease $[123,124]$. Also, in people with autoimmune diseases, the presence of intestinal nematodes in the body resulted in the inhibition of excessive inflammatory reaction and, as a consequence, symptoms of diseases such as non-specific inflammatory diseases of the intestines. The therapy can also be used in patients with psoriasis, autism and rheumatoid arthritis $[115,123]$. Intensive research is also being conducted into the utilization of the positive aspect of such parasites as whipworm (Trichuris suis) and hookworm (Nacator americanus) in Crohn's disease and ulcerative colitis [125].

Risks of parasite use in medical treatment. Clinical examination conducted to-date on the use of parasites in the treatment of autoimmune or allergic diseases, gives rise to a number of controversies, but also present a certain potential of such studies. Clinical treatment with parasites must be carried out with special care and may have many sideeffects. In parasitic infection, the species of parasite causing the infection, its form (larval, adult), time of infection, the number of parasites and individual characteristics of the host organism are of crucial significance. Having the knowledge of what kind of parasite to be used in the treatment is not enough; more importantly, it should be determined what amount of parasite should be introduced, whether there will be a different negative reaction, and how a given immune system of a given host will behave [126, 127]. Parasites use our nutrition products, often causing vitamin deficiencies, e.g. the supply of broad fish tapeworm (Diphyllobothrium latum) for vitamin B12 [128]. Parasites compete with us for food and cause deficiencies, and are also a source of toxins and allergic factors. They also pose a threat in the event of their death by releasing a number of toxins into the human body that may lead to anaphylactic shock. Also the reproduction of parasites within the human organism can lead to serious consequences which can be the cause of infection of third persons, as well as self-infection (both ecto-infection and endo-infection), e.g. as a result of invasion of dwarf tapeworm (Hymenolepis nana) [129]. Unfortunately, another negative aspect is the location of parasites within the human organism which, in spite of the fact that in many species it is known it may proceed in a different way. An example of this is the common liver fluke Fasciola hepatica, a parasite of the bile duct in the liver; however, these parasites sometimes travel with in the blood circulation to the lungs, brain and muscles, causing abnormal symptoms of fasciolosis $[130,131$.$] Especially dangerous in$ this respect are larval forms of various parasites, which may cause the syndrome of migrating visceral larvae [132].

The most common symptoms in parasite infections are: muscle pains, fever, weakness and intestinal disorders. Their presence in various organs can often cause a long-lasting inflammatory state. This condition, caused by many parasite species, carries one of the greatest dangers when used with helminth therapy. This danger is associated with cancer and high mortality. These include many species of trematode parasites (of the Schistosoma type, causing tumours of the urinary bladder and the intestine, or one of the tapeworms most pathogenic for humans - Echinococcus multilocularis, responsible for liver damage $[133,134]$.

The use of anti-parasitic preparations and eggs or larvae of parasites of unknown origin is very dangerous. The chemical composition of such a preparation is usually unknown and can be harmful, and even if it affects parasites it can have negative consequences, e.g. convolution and penetration of parasites into the peritoneal cavity, such as human roundworm - Ascaris lumbricoides [135]. The possibility of buying pills in the case of the so-called "Tapeworm diet" entails many risks. Firstly, it is not known what such pills contain, secondly, before the tapeworm grows - most often the infection will be asymptomatic or poorly symptomatic - weight loss will jot be achieved. Thirdly, it is not known 
how the body is going to behave, and whether infection with another species of dangerous parasite has also occurred, which can prove to be lethal. Such a species can be, e.g. the armed tapeworm - Taenia solium, whose larvae can cause dangerous cysticercosis [136].

Although there is a great deal of research on the use of parasites in medicine, especially in support of the human immune system, which gives promising results, the danger and consequences outweigh the risk of therapy over the benefits [127]. Even in the absence of negative effects of contact with a parasite, it not known what the consequences may be incurred after the death of the parasite in the distant future, especially when they are the factors responsible for the development of cancer.

\section{CONCLUSIONS}

In the light of the latest research presenting the unconventional use of parasitic forms in medicine, the widely understood impact of parasites on the human body can also be considered in a positive context. The presented examples of the positive effects of parasites, especially in the suppression of immune system of the host, give hope for the future in terms of fighting some diseases for which pharmacological treatment has not yet brought a full, positive effect.

\section{Acknowledgments}

This work was supported under the program of the Minister of Science and Higher Education under name "Regional Initiative of Excellence in 2019-2022 project number: 024/ RID/2018/19, financing amount: 11.999.000,00 PLN.

\section{REFERENCES}

1. Leggett HC, Cornwallis CK, West SA. Mechanisms of pathogenesis, infective dose and virulence in human parasites. PLoS Pathog. 2012; 8(2): e1002512. https://doi.org/10.1371/journal.ppat.1002512

2. Hadaś E, Derda M. Pasożyty - zagrożenia nadal aktualne [Parasites are still dangerous]. Problemy Higieny i Epidemiologii. 2014; 95(1): 6-13. [in Polish]

3. Horwitz P, Wilcox BA. Parasites, ecosystems and sustainability: an ecological and complex systems perspective. Int J Parasitol. 2005; 35(7): 725-732. https://doi.org/10.1016/j.ijpara.2005.03.002

4. International Helminth Genomes Consortium. Comparative genomics of the major parasitic worms. Nat Genet. 2018; 51(1): 163-174. https:// doi.org/10.1101/236539

5. Harder A. The Biochemistry of Haemonchus contortus and Other Parasitic Nematodes. Adv Parasitol. 2016; 93: 69-94. https://dx.doi. org/10.1016/bs.apar.2016.02.010

6. Blume M, Seeber F. Metabolic interactions between Toxoplasma gondii and its host. F1000Res. 2018; 7:F1000 Faculty Rev-1719. https://doi. org/10.12688/f1000research.16021.1

7. Baptista-Fernandesa T, Rodriguesb M, Castrob I, Paixãoc P, PintoMarquesd P, Roquee L, Belof S, Manuel Ferreiraf P, Mansinhog K, Toscanoa C. Human gastric hyperinfection by Anisakis simplex: A severe and unusual presentation and a brief review. Int J Infect Dis. 2017; 64: 38-41. https://doi.org/ 10.1016/j.ijid.2017.08.012

8. Liu Q, Wei F, Liu W, Yang S, Zhang X. Paragonimiasis: an important food-borne zoonosis in China. Trends Parasitol. 2008; 24(7): 318-23. https://doi.org/ 10.1016/j.pt.2008.03.014.

9. Robertson LJ, van der Giessen JW, Batz MB, Kojima M, Cahill S. Have foodborne parasites finally become a global concern? Trends Parasitol. 2013; 29(3): 101-3. https://doi.org/ 10.1016/j.pt.2012.12.004.

10. R.C Thompson. Parasites and food: ripe for exploitation. Trends Parasitol. 2014; 30(1) 1-3. https://doi.org/ 10.1016/j.pt.2013.09.006.

11. Sripa B. Global burden of food-borne trematodiasis. Lancet Infect Dis. 2012; 12(3): 171-2. https://doi.org/ 10.1016/S1473-3099(11)70321-8.
12. Trevisan C, Sotiraki S, Laranjo-González M, Dermauw V, Wang Z, Kärssin A, Cvetkovikj A, Winkler AS, Abraham A, Bobić B, Lassen B, Cretu CM, Vasile C, Arvanitis D, Deksne G, Boro I, Kucsera I, Karamon J, Stefanovska J, Koudela B, Pavlova MJ, Varady M, Pavlak M, Šarkūnas M, Kaminski M, Djurković-Djaković O, Jokelainen P, Jan DS, Schmidt V, Dakić Z, Gabriël S, Dorny P, Omeragić J, Alagić D, Devleesschauwer B. Epidemiology of taeniosis/cysticercosis in Europe, a systematic review: eastern Europe. Parasit Vectors. 2018; 11(1): 569. https://doi.org/10.1186/s13071-018-3153-5.

13. Shahnazi M, Abdollahpour H, Alipour M, Sadeghi M, Saraei M, Hajialilo E, Heydarian P. Prevalence of intestinal parasites in food handlers of the city of Saqqez in 2016. J Parasit Dis. 2019; 43(1): 113-119. https://doi.org/10.1007/s12639-018-1065-0.

14. Saad NM, Hussein AAA, Ewida RM. Occurrence of Toxoplasma gondii in raw goat, sheep, and camel milk in Upper Egypt. Vet World. 2018; 11(9): 1262-1265. https://doi.org/10.14202/vetworld.2018.1262-1265.

15. Furuya K, Nakajima H, Sasaki Y, Urita Y. Anisakiasis: The risks of seafood consumption. Niger J Clin Pract. 2018; 21(11): 1492-1494. https://doi.org/10.4103/njcp.njcp_256_17.

16. Cox FE. History of human parasitology. Clin Microbiol Rev. 2002; 15(4): 595-612. https://doi.org/10.1128/cmr.15.4.595-612.2002

17. Doni NY, Gürses G, Simșek Z, Zeyrek FY. Prevalence and associated risk factors of intestinal parasites among children of farm workers in the southeastern Anatolian region of Turkey. Ann Agric Environ Med. 2015; 22(3): 438-442. https://doi.org/10.5604/12321966.1167709

18. Haque R. Human intestinal parasites. J Health Popul Nutr. 2007; 25(4): 387-391.

19. Hotez PJ, Gurwith M. Europe's neglected infections of poverty. Int J Infect Dis. 2011; 15(9): e611-9. https://doi.org/10.1016/j.ijid.2011.05.006

20. Pawłowski Z. [Sytuacja zdrowotna w świecie $z$ uwzględnieniem wybranych inwazji pasożytniczych w Polsce] Global health situation with emphasis on selected parasitic infections in Poland. Wiad Parazytol. 2008; 54(1): 17-22. [in Polish]

21. Amer OSO, Al-Malki ES, Waly MI, AlAgeel A, Lubbad MY. Prevalence of Intestinal Parasitic Infections among Patients of King Fahd Medical City in Riyadh Region, Saudi Arabia: A 5-Year Retrospective Study. J Parasitol Res. 2018; 2018: 8076274. https://doi.org/10.1155/2018/8076274

22. Andrews RM, McCarthy J, Carapetis JR, Currie BJ. Skin Disorders, Including Pyoderma, Scabies, and Tinea Infections. Pediatr Clin North Am. 2009; 56(6): 1421-1440. https://doi.org/10.1016/j.pcl.2009.09.002.

23. Defty C, Breitenfeldt N, Dhital SK, Juma A. Demodex folliculorum: A parasite infection mimicking skin cancer. J Plast Reconstr Aesthet Surg. 2013; 66(2): 289-90. https://doi.org/10.1016/j.bjps.2012.08.028.

24. Christine C. Jacobson MD and Elizabeth A. Abel MD. Parasitic infestations. J AM Acad Dermatol. 2007; 56(6): 1026-1043. https:// doi.org/10.1016/j.jaad.2006.10.963

25. Chandler DJ, Fuller LC. A Review of Scabies: An Infestation More than Skin Deep. Dermatology. 2019; 235(2): 79-90. https://doi. org/10.1159/000495290

26. Giacomin P, Zakrzewski M, Jenkins TP, Su X, Al-Hallaf R, Croese J, de Vries S, Grant A, Mitreva M, Loukas A, Krause L, Cantacessi C. Changes in duodenal tissue-associated microbiota following hookworm infection and consecutive gluten challenges in humans with coeliac disease. Sci Rep. 2016; 96: 36797. https://doi.org/10.1038/srep36797.

27. Sharma V, Gunjan D, Chhabra P, Sharma R, Rana SS, Bhasin DK. Gastrointestinal bleeding in the tropics: Look for the hookworm. Trop Doct. 2017;47(1): 48-51. https://doi.org/10.1177/0049475516640192

28. Andrade AM, Perez Y, Lopez C, Collazos SS, Andrade AM, Ramirez GO, Andrade LM. Intestinal Obstruction in a 3-Year-Old Girl by Ascaris lumbricoides Infestation: Case Report and Review of the Literature. Medicine (Baltimore). 2015; 94(16): e655. https://doi. org/10.1097/MD.0000000000000655

29. Takamizawa Y, Kobayashi Y. Adhesive intestinal obstruction caused by extragastrointestinal anisakiasis. Am J Trop Med Hyg. 2015; 92(4): 675-676. https://doi.org/10.4269/ajtmh.14-0673

30. Yıldız T, İlçe Z, Turan G, Bozdağ Z, Elmas B. Parasites in the Etiology of Pediatric Appendicitis. Turkiye Parazitol Derg. 2015; 39(3): 190-3. https://doi.org/10.5152/tpd.2015.3737

31. Agrawal R. Soft tissue cysticercosis: study of 21 cases. J Clin Diagn Res. 2012;6(10): 1669-71. https://doi.org/ 10.7860/JCDR/2012/4297.2641.

32. Gnanamoorthy K, Suthakaran PK. Disseminated cysticercosis in an immunocompetent individual. Ann Afr Med. 2019; 18(1): 51-53. https:// doi.org/10.4103/aam.aam_76_17.

33. Kashyap B, Samantray JC, Kumar S, Jhamb R, Singh AK, Kaur IR. Recurrent paediatric pinworm infection of the vagina as a potential reservoir for Enterobius vermicularis. J Helminthol. 2014; 88(3): 381383. https://doi.org/10.1017/S0022149X13000345 
34. Lamberton PH, Jourdan PM. Human Ascariasis: Diagnostics Update. Curr Trop Med Rep. 2015; 2(4): 189-200. https://doi.org/10.1007/ s40475-015-0064-9

35. Zaglool DA, Khodari YA, Othman RA, Farooq MU. Prevalence of intestinal parasites and bacteria among food handlers in a tertiary care hospital. Niger Med J. 2011; 52(4): 266-270. https://dx.doi. org/10.4103/0300-1652.93802

36. Stark D, van Hal S, Marriott D, Ellis J, Harkness J. Irritable bowel syndrome: a review on the role of intestinal protozoa and the importance of their detection and diagnosis. Int J Parasitol. 2007; 37(1): 11-20. https://doi.org/10.1016/j.ijpara.2006.09.009

37. Ntoukas V, Tappe D, Pfütze D, Simon M, Holzmann T. Cerebellar cysticercosis caused by larval Taenia crassiceps tapeworm in immunocompetent woman, Germany. Emerg Infect Dis. 2013; 19(12): 2008-11. https://dx.doi.org/10.3201/eid1912.130284

38. Sharma K, Wijarnpreecha K, Merrell N. Diphyllobothrium latum Mimicking Subacute Appendicitis. Gastroenterology Res. 2018; 11(3): 235-237. https://doi.org/10.14740/gr989w

39. Jourdan PM, Lamberton PHL, Fenwick A, Addiss DG. Soil-transmitted helminth infections. Lancet. 2018; 391(10117): 252-265. https://doi. org/10.1016/S0140-6736(17)31930-X.

40. Bruschi F, Araujo MI, Harnett W, Pinelli E. Allergy and parasites. J Parasitol Res. 2013;2013:502562.https://dx.doi.org/10.1155/2013/502562

41. Opara KN, Udoidung NI, Opara DC, Okon OE, Edosomwan EU, Udoh AJ. The Impact of Intestinal Parasitic Infections on the Nutritional Status of Rural and Urban School-Aged Children in Nigeria. Int J MCH AIDS. 2012; 1(1): 73-82.

42. Toh SQ, Glanfield A, Gobert GN, Jones MK. Heme and blood-feeding parasites: friends or foes? Parasit Vectors. 2010; 3: 108. https://doi. org/10.1186/1756-3305-3-108

43. Kořený L, Oborník M, Lukeš J. Make it, take it, or leave it: heme metabolism of parasites. PLoS Pathog. 2013; 9(1): e1003088. https:// doi.org/10.1371/journal.ppat.1003088

44. Vuylsteke P, Bertrand C, Verhoef GE, Vandenberghe P. Case of megaloblastic anemia caused by intestinal taeniasis. Ann Hematol. 2004; 83(7): 487-488. https://doi.org/10.1007/s00277-003-0839-2

45. White RR, Ponsford AH, Weekes MP, Rodrigues RB, Ascher DB, Mol M, Selkirk ME, Gygi SP, Sanderson CM, Artavanis-Tsakonas K. Ubiquitin-Dependent Modification of Skeletal Muscle by the Parasitic Nematode, Trichinella spiralis. PLoS Pathog. 2016; 12(11): e1005977. https://doi.org/ 10.1371/journal.ppat.1005977

46. Norouzi R, Manochehri A, Hanifi M. A Case Report of Human Infection with Dioctophyma Renale from Iran. Urol J. 2017; 14(2): 3043-3045.

47. Kuehn J, Lombardo L, Janda WM, Hollowell CM. Giant kidney worms in a patient with renal cell carcinoma. BMJ Case Rep. 2016; pii: bcr2015212118. https://doi.org/10.1136/bcr-2015-21211

48. Beiting DP, Park PW, Appleton JA. Synthesis of syndecan-1 by skeletal muscle cells is an early response to infection with Trichinella spiralis but is not essential for nurse cell development. Infect Immun. 2006; 74(3): 1941-1943. https://dx.doi.org/10.1128/IAI.74.3.1941-1943.2006

49. Norouzi R, Manochehri A, Hanifi M. A Case Report of Human Infection with Dioctophyma Renale from Iran. Urol J. 2017; 14(2): 3043-3045.

50. Chauhan S, Kaval S, Tewari S. Dioctophymiasis: A Rare Case Report. J Clin Diagn Res. 2016; 10(2): DD01-2. https://dx.doi.org/10.7860/ JCDR/2016/17394.7305

51. Deere JR, Parsons MB, Lonsdorf EV, Lipende I, Kamenya S, Collins DA, Travis DA, Gillespie TR. Entamoeba histolytica infection in humans, chimpanzees and baboons in the Greater Gombe Ecosystem, Tanzania. Parasitology. 2018: 1-7. https://dx.doi.org/10.1017/S0031182018001397

52. Gurung P, Kanneganti TD. Immune responses against protozoan parasites: a focus on the emerging role of Nod-like receptors. Cell Mol Life Sci. 2016; 73(16):3035-3051.https://dx.doi.org/10.1007/s00018-016-2212-3

53. Koko J, Ategbo SJ, Gahouma D, Engohan-Aloghe E, Moussavou A. Human African trypanosomiasis: report of three cases. Arch Pediatr. 2013; 20(8): 871-3. https://doi.org/ 10.1016/j.arcped.2013.05.018

54. Ponte-Sucre A. An Overview of Trypanosoma brucei Infections: An Intense Host-Parasite Interaction. Front Microbiol. 2016; 7: 2126. https://dx.doi.org/10.3389/fmicb.2016.02126

55. Overgaauw PA. Aspects of Toxocara epidemiology: human toxocarosis. Crit Rev Microbiol. 1997; 23(3): 215-231. https://dx.doi. org/10.3109/10408419709115137

56. Pawlowski Z. Toxocariasis in humans: clinical expression and treatment dilemma. J Helminthol. 2001; 75(4): 299-305.

57. Macpherson CN. The epidemiology and public health importance of toxocariasis: a zoonosis of global importance. Int J Parasitol. 2013; 43(12-13): 999-1008. https://dx.doi.org/10.1016/j. ijpara.2013.07.004.
58. Sánchez SS, García HH, Nicoletti A. Clinical and Magnetic Resonance Imaging Findings of Neurotoxocariasis. Front Neurol. 2018; 9: 53. https://dx.doi.org/10.3389/fneur.2018.00053

59. Despommier D. Toxocariasis: clinical aspects, epidemiology, medical ecology, and molecular aspects. Clin Microbiol Rev. 2003; 16(2): 265272. https://dx.doi.org/10.1128/CMR.16.2.265-272.2003

60. Schmid-Hempel P. Immune defence, parasite evasion strategies and their relevance for 'macroscopic phenomena' such as virulence. Philos Trans R Soc Lond B Biol Sci. 2009; 364(1513): 85-98. https:// doi.org/10.1098/rstb.2008.0157

61. Hewitson JP, Grainger JR, Maizels RM. Maizels Helminth immunoregulation: The role of parasite secreted proteins in modulating host immunity. Mol Biochem Parasitol. 2009; 167(1): 1-11. https://doi. org/10.1016/j.molbiopara.2009.04.008

62. Smallwood TB, Giacomin PR, Loukas A, Mulvenna JP, Clark RJ, Miles JJ. Helminth Immunomodulation in Autoimmune Disease. Front Immunol. 2017 Apr 24; 8: 453. https://doi.org/10.3389/fimmu.2017.00453

63. Maizels RM, McSorley HJ. Regulation of the host immune system by helminth parasites. J Allergy Clin Immunol. 2016; 138(3): 666-675. https://doi.org/10.1016/j.jaci.2016.07.007

64. Yazdanbakhsh M, Sacks DL. Why does immunity to parasites take so long to develop? Nat Rev Immunol. 2010; 10(2): 80-81. https://dx.doi. org/10.1038/nri2673

65. Mohammadi R, Hosseini-Safa A, Ehsani Ardakani MJ, Rostami-Nejad $M$. The relationship between intestinal parasites and some immunemediated intestinal conditions. Gastroenterol Hepatol Bed Bench. 2015; 8(2): 123-131.

66. Sorobetea D, Svensson-Frej M, Grencis R. Immunity to gastrointestinal nematode infections. Mucosal Immunol. 2018; 11(2): 304-315. https:// dx.doi.org/10.1038/mi.2017.113

67. Yasuda K, Nakanishi K. Host responses to intestinal nematodes. Int Immunol. 2018; 30(3): 93-102. https://dx.doi.org/10.1093/intimm/ dxy002

68. Coutermarsh-Ott S.Toxoplasma gondii as a Model of In Vivo HostParasite Interactions. Methods Mol Biol. 2019; 1960: 237-247. https:// doi.org/ 10.1007/978-1-4939-9167-9_21

69. Saucet SB, Shirasu K. Molecular Parasitic Plant-Host Interactions. PLoS Pathog. 2016; 12(12): e1005978. https://dx.doi.org/10.1371/journal. ppat.1005978

70. Paciello O, Palmieri C, Otrocka-Domagala I, Rinaldi L, MoralesMontor J, Geldhof P. Immunopathology of Parasitic Infections and Therapeutic Approaches in Humans and Animals. Biomed Res Int. 2016; 2016: 8213532. https://dx.doi.org/10.1155/2016/8213532

71. Hewitson JP, Grainger JR, Maizels RM. Helminth immunoregulation: the role of parasite secreted proteins in modulating host immunity. Mol Biochem Parasitol. 2009; 167(1): 1-11. https://dx.doi.org/10.1016/j. molbiopara.2009.04.008

72. Keller CC, Davenport GC, Dickman KR, Hittner JB, Kaplan SS, Weinberg JB, Kremsner PG, Perkins DJ. Suppression of prostaglandin E2 by malaria parasite products and antipyretics promotes overproduction of tumor necrosis factor-alpha: association with the pathogenesis of childhood malarial anemia. J Infect Dis. 2006; 193(10): 1384-1393. https://dx.doi.org/10.1086/503047

73. Deroost K, Pham TT, Opdenakker G, Van den Steen PE. The immunological balance between host and parasite in malaria. FEMS Microbiol Rev. 2016; 40(2): 208-257. https://dx.doi.org/10.1093/femsre/fuv046

74. Maier AG, Matuschewski K, Zhang M, Rug M.Plasmodium falciparum. Trends Parasitol. 2018; S1471-4922(18) 30248-4. https://doi. org/10.1016/j.pt.2018.11.010

75. Fabre MV, Beiting DP, Bliss SK, Appleton JA. Immunity to Trichinella spiralis muscle infection. Vet Parasitol. 2009; 159(3-4): 245-8. https:// doi.org/10.1016/j.vetpar.2008.10.051

76. Paul AS, Egan ES, Duraisingh MT. Host-parasite interactions that guide red blood cell invasion by malaria parasites. Curr Opin Hematol. 2015; 22(3): 220-226. https://dx.doi.org/10.1097/MOH.0000000000000135

77. Kulkarni MM, Jones EA, McMaster WR, McGwire BS. Fibronectin binding and proteolytic degradation by Leishmania and effects on macrophage activation. Infect Immun. 2008; 76(4): 1738-1747. https:// dx.doi.org/10.1128/IAI.01274-07

78. Piña-Vázquez C, Reyes-López M, Ortíz-Estrada G, de la Garza M, Serrano-Luna J. Host-parasite interaction: parasite-derived and -induced proteases that degrade human extracellular matrix. J Parasitol Res. 2012; 2012: 748206. https://dx.doi.org/10.1155/2012/748206

79. Doligalska M. Regulacja reakcji obronnej i alergicznej w inwazji pasożytów [Regulation of defense and allergic reactions in parasite invasion]. Wiadomości parazytologiczne. 2000; 46(1): 3-20. [in Polish] 
80. El-Malky M, Nabih N, Heder M, Saudy N, El-Mahdy M. Helminth infections: therapeutic potential in autoimmune disorders. Parasite Immunol. 2011; 33(11): 589-593. https://dx.doi.org/10.1111/j.13653024.2011.01324.x

81. Pritchard DI. Worm therapy: How would you like your medicine? Int J Parasitol Drugs Drug Resist. 2012; 2: 106-108. https://dx.doi. org/10.1016/j.ijpddr.2012.02.001

82. Rados C. Beyond blooding: FDA gives leeches amedicinal makeover. FDA Consum. 2004; 38(5): 9.

83. Munshi Y, Ara I, Rafique H, Ahmad Z. Leeching in the historya review. Pak J Biol Sci. 2008; 11(13): 1650-1653.

84. Eldor A, Orevi M, Rigbi M. The role of the leech in medical therapeutics. Blood Rev. 1996; 10(4): 201-9.

85. Gronwald W, Bomke J, Maurer T, Domogalla B, Huber F, Schumann F, Kremer W, Fink F, Rysiok T, Frech M, Kalbitzer HR. Structure of the leech pro-tein saratin and characterization of its binding to collagen. J Mol Biol. 2008; 381(4): 913-27. https://doi.org/10.1016/j.jmb.2008.06.034

86. Kose A, Zengin S, Kose B, Gunay N, Yildirim C, Kilinc H, Togun I. Leech bites: massive bleeding, co-agulation profile disorders, and severe anemia. Am J Emerg Med. 2008, 26(9): 1067.e3-6. https://doi. $\operatorname{org} / 10.1016 /$ j.ajem.2008.03.022

87. Laufer AS, Siddall ME, Graf J. Characterization of the digestive-tract microbiota of Hirudo orientalis, a european medicinal leech. Appl Environ Microbiol. 2008; 74(19): 6151-4. https:/doi.org/10.1128/ AEM.00795-08

88. Knobloch K, Gohritz A, Busch K, Spies M, Vogt PM. Hirudo medicinalis - leech applications in plastic and reconstructive microsurgery - a literature review Handchir Mikrochir Plast Chir. 2007; 39(2): 103-7.

89. Baskova IP, Zavalova LL. Polyfunctionality of destabilase, a lyso-zyme from a medicinal leech. Bioorg Khim. 2008; 34(3): 337-43.

90. Chalisova NI, Baskova IP, Zavalova LL, Pennijainen VA. Neuritestimulating effect of Hirudo medicinalis salivary gland secreting factors in orga-notypic culture of the dorsal root ganglia. Ross Fiziol Zh Im I M Sechenova. 2001; 87(6): 815-20.

91. Rudkowska J. Regulation of the parasite-host immune system at the cellular level. Nowiny lekarskie 2007; 76(3): 251-255. [in Polish]

92. Versini M, Jeandel PY, Bashi T, Bizzaro G, Blank M, Shoenfeld Y. Unraveling the Hygiene Hypothesis of helminthes and autoimmunity: origins, pathophysiology, and clinical applications. BMC Med. 2015; 13: 81. https://dx.doi.org/10.1186/s12916-015-0306-7

93. Cooper PJ, Chico ME, Rodrigues LC, Ordonez M, Strachan D, Griffin GE, Nutman TB. Reduced risk of atopy among school-age children infected with geohelminth parasites in a rural area of the tropics. J Allergy Clin Immunol. 2003; 111: 995-1000. https://dx.doi. org/10.1067/mai.2003.1348

94. van den Biggelaar AH, Rodrigues LC, van Ree R, van der Zee JS, HoeksmaKruize YC, Souverijn JH, Missinou MA, Borrmann S, Kremsner PG, Yazdanbakhsh M. Long-term treatment of intestinal helminths increases mite skin-test reactivity in Gabonese schoolchildren. J Infect Dis. 2004; 189: 892-900. https://dx.doi.org/10.1086/381767

95. Araujo MI, Lopes AA, Medeiros M, Cruz AA, Sousa-Atta L, Solé D, Carvalho EM. Inverse association between skin response to aeroallergens and Schistosoma mansoni infection. Int Arch Allergy Immunol. 2000; 123: 145-148. https://dx.doi.org/10.1159/000024433

96. Lynch NR, Hagel I, Perez M, Di Prisco MC, Lopez R, Alvarez N. Effect of anthelmintic treatment on the allergic reactivity of children in tropical slum. J Allergy Clin Immunol. 1993; 92: 404-411. https:// dx.doi.org/10.1016/0091-6749(93)90119-Z.

97. Flohr C, Tuyen LN, Lewis S, Quinnell R, Minh TT, Liem HT, Campbell J, Pritchard D, Hien TT, Farrar J, Williams H, Britton J. Poor sanitation and helminth infection protect against skin sensitization in Vietnamese children: a cross-sectional study. J Allergy Clin Immunol. 2006; 118: 1305-1311. https://dx.doi.org/10.1016/j.jaci.2006.08.035

98. Hotez PJ, Brindley PJ, Bethony JM, King CH, Pearce EJ, Jacobson J. Helminth infections: the great neglected tropical diseases. J Clin Invest. 2008; 118: 1311-1321. https://dx.doi.org/10.1172/JCI34261

99. Leonardi-Bee J, Pritchard D, Britton J. Asthma and current intestinal parasite infection: systematic review and meta-analysis. Am J Respir Crit Care Med. 2006; 174(5): 514-523. https://dx.doi.org/10.1164/ rccm.200603-331OC

100. Bakiri AH, Mingomataj EC. Parasites induced skin allergy: a strategic manipulation of the host immunity. J Clin Med Res. 2010; 2(6): 247-255. https://dx.doi.org/10.4021/jocmr456w

101. Mingomataj EC, Xhixha F, Gjata E. Helminths can protect themselves against rejection inhibiting hostile respiratory allergy symptoms. Allergy. 2006; 61(4): 400-406. https://dx.doi.org/10.1111/j.1398 9995.2006.00983.x
102.Amoah AS, Boakye DA, Yazdanbakhsh M, van Ree R. Influence of Parasitic Worm Infections on Allergy Diagnosis in Sub-Saharan Africa. Curr Allergy Asthma Rep. 2017; 17(10): 65. https://dx.doi. org/10.1007/s11882-017-0733-y

103. Harnett W. Secretory products of helminth parasites as immunomodulators. Mol Biochem Parasitol. 2014; 195(2): 130-136. https://dx.doi.org/10.1016/j.molbiopara.2014.03.007

104. Smallwood TB, Giacomin PR, Loukas A, Mulvenna JP, Clark RJ, Miles JJ. Helminth Immunomodulation in Autoimmune Disease. Front Immunol. 2017; 8: 453. https://dx.doi.org/10.3389/fimmu.2017.00453

105. Apaer S, Tuxun T, Ma HZ, Zhang H, Aierken A, Aini A, Li YP, Lin RY, Wen H. Parasitic infection as a potential therapeutic tool against rheumatoid arthritis. Exp Ther Med. 2016; 12(4): 2359-2366. http:// dx.doi.org/10.3892/etm.2016.3660

106. Maizels RM. Parasitic helminth infections and the control of human allergic and autoimmune disorders. Clin Microbiol Infect. 2016; 22(6): 481-486. https://dx.doi.org/10.1016/j.cmi.2016.04.024

107. Górska S, Jarzab A, Gamian A. Bakterie probiotyczne w przewodzie pokarmowym człowieka jako czynnik stymulujacy układ odpornościowy [Probiotic bacteria in the human gastrointestinal tract as a factor stimulating the immune system]. Postepy Hig Med Dosw. 2009; 63: 653-667. [in Polish]

108. Berrilli F, Di Cave D, Cavallero S, D'Amelio S. Interactions between parasites and microbial communities in the human gut. Front Cell Infect Microbiol. 2012; 2: 141. https://dx.doi.org/10.3389/fcimb.2012.00141G

109. Summers RW, Elliott DE, Urban JF Jr, Thompson RA, Weinstock JV. Trichuris suis therapy for active ulcerative colitis: a randomized controlled trial. Gastroenterol. 2005; 128: 825-832. https://doi. org/10.1053/j.gastro.2005.01.005

110. Summers RW, Elliott DE, Urban JF, Thompson R, Weinstock JV. Trichuris suis therapy in Crohn's disease. Gut 2015; 54: 87-90. https:// dx.doi.org/10.1136/gut.2004.041749

111. Wu S, Li RW, Li W, Beshah E, Dawson HD, Urban JF Jr. Worm burdendependent disruption of the porcine colon microbiota by Trichuris suis infection. PLoS One. 2012; 7(4): e35470. https://dx.doi.org/10.1371/ journal.pone.0035470

112. Travers MA, Florent I, Kohl L, Grellier P. Probiotics for the control of parasites: an overview. J Parasitol Res. 2011; 2011: 610769. https:// dx.doi.org/10.1155/2011/610769

113. Devaney E. Parasites, probiotics, and piglets: a novel approach to IBD. Mol Ther. 2014; 22(10): 1722-1723. https://dx.doi.org/10.1038/mt.2014.168

114. Sant'Anna MR, Diaz-Albiter H, Aguiar-Martins K, Al Salem WS, Cavalcante RR, Dillon VM, Bates PA, Genta FA, Dillon RJ. Colonisation resistance in the sand fly gut: Leishmania protects Lutzomyia longipalpis from bacterial infection. Parasit Vectors. 2014; 7: 329. https://dx.doi.org/10.1186/1756-3305-7-329

115. Fleming JO, Isaak A, Lee JE, Luzzio CC, Carrithers MD, Cook TD, Field AS, Boland J, Fabry Z. Probiotic helminth administration in relapsing-remitting multiple sclerosis: a phase 1 study. Mult Scler. 2011; 17(6): 743-754. https://dx.doi.org/10.1177/1352458511398054

116. Barzdo M, Żydek L, Michalski M, Meissner E, Berent J. Wykorzystanie metod entomologicznych do oceny czasu zgonu - opis przypadków [The use of entomological methods in determination of the time of death - case presentations]. Arch Med Sąd Krym. 2007; 57: 351-354. [in Polish]

117. Rafał S, Czesław Ch. Polska entomologia sądowa - rys historyczny, stan obecny i perspektywy na przyszłość [Polish forensic entomology - the past, present and future perspectives]. Arch Med Sąd Krym. 2010; 65: 55-58. [in Polish]

118. Khachatryan AS. Analysis of Lethality in Echinococcal Disease. Korean J Parasitol. 2017; 55(5): 549-553. https://doi.org/10.3347/ kjp.2017.55.5.549

119. Raposio E, Bortolini S, Maistrello L, Grasso DA. Larval Therapy for Chronic Cutaneous Ulcers: Historical Review and Future Perspectives. Wounds. 2017; 29(12): 367-373.

120. Orkiszewski M. Zastosowanie larw muchy Lucilla sericata w leczeniu trudno gojących się ran [Maggots of Lucilia sericata in treatment of intractable wounds]. Wiad Lek. 2007; 60 (7-8): 381-385. [in Polish]

121. Thomas S, Jones M, Shutler S, Jones S. Using larvae in modern wound management. J Wound Care 1996; 5: 60-69.

122. Hobson RP. On an enzyme from blow-fly larvae [Lucilia sericata] which digests collagen in alkaline solution. Biochem J. 1931; 25(5): 1458-1463.

123. Helmby H. Human helminth therapy to treat inflammatory disorders - where do we stand? BMC Immunol. 2015; 16: 12. https://dx.doi. org/10.1186/s12865-015-0074-3

124.La Flamme AC, Ruddenklau K, Bäckström BT. Schistosomiasis decreases central nervous system inflammation and alters the 
progression of experimental autoimmune encephalomyelitis. Infect Immun. 2003; 71(9): 4996-5004. https://dx.doi.org/10.1128/ IAI.71.9.4996-5004.2003

125. Sandborn WJ, Elliott DE, Weinstock J, Summers RW, Landry-Wheeler A, Silver N, Harnett MD, Hanauer SB. Randomised clinical trial: the safety and tolerability of Trichuris suis ova in patients with Crohn's disease. Aliment Pharmacol Ther. 2013; 38(3): 255-263. https://dx.doi. org/10.1111/apt.12366

126. Ulrich Y, Schmid-Hempel P. Host modulation of parasite competition in multiple infections. Proc Biol Sci. 2012; 279(1740): 2982-9. https:// doi.org/10.1098/rspb.2012.0474

127. Helmby H. Human helminth therapy to treat inflammatory disorderswhere do we stand? BMC Immunol. 2015; 16: 12. https://doi.org/10.1186/ s12865-015-0074-3.

128.Zabrocka J, Wojszel ZB. Niedobór witaminy B12 w wieku podeszłym - przyczyny, następstwa, podejście terapeutyczne [Vitamin B12 deficiency in old age - causes, consequences and therapeutic approach]. Geriatria 2013; 7: 24-32. [in Polish]

129. Kim BJ, Song KS, Kong HH, Cha HJ, Ock M. Heavy Hymenolepis nana infection possibly through organic foods: report of a case. Korean J Parasitol. 2014; 52(1): 85-87. https://dx.doi.org/10.3347/ kjp.2014.52.1.85

130. Montembault S, Serfaty L, Poirot JL, Wendum D, Penna C, Poupon R. Hemorrhagic ascites disclosing massive Fasciola hepatica infection. Gastroenterol Clin Biol. 1997; 21(10): 785-8.

131. Mas-Coma S, Agramunt VH, Valero MA.Direct and indirect affection of the central nervous system by Fasciola infection. Handb Clin
Neurol. 2013; 114: 297-310. https://doi.org/10.1016/B978-0-444-534903.00024-8

132. Yoshida A, Hombu A, Wang Z, Maruyama H. Larva migrans syndrome caused by Toxocara and Ascaris roundworm infections in Japanese patients. Eur J Clin Microbiol Infect Dis. 2016; 35(9): 1521-1529. http:// dx.doi.org/10.1007/s10096-016-2693-x

133. Narasimhan PB, Akabas L, Tariq S, Huda N, Bennuru S, Sabzevari H, Hofmeister R, Nutman TB, Tolouei Semnani R. Similarities and differences between helminth parasites and cancer cell lines in shaping human monocytes: Insights into parallel mechanisms of immune evasion. PLoS Negl Trop Dis. 2018; 12(4): e0006404. https://dx.doi. org/10.1371/journal.pntd.0006404

134. Maruszewska-Cheruiyot M, Donskow-Łysoniewska K, Doligalska M. Helminth therapy: Advances in the use of parasitic worms against Inflammatory Bowel Diseases and its challenges. Helminthologia. 2018; 55(1): 1-11

135. Gupta S, Kumar S, Satapathy A, Ray U, Chatterjee S, Choudhury TK. Ascaris lumbricoides: an unusual aetiology of gastric perforation. J Surg Case Rep. 2012; 2012(11). pii: rjs008. https://doi.org/10.1093/ jscr/rjs008

136. Song EK, Kim IH, Lee SO. Unusual manifestations of Taenia solium infestation. J Gastroenterol. 2004; 39(3): 288-291. https://dx.doi. org/10.1007/s00535-003-1291-8

137. Smallwood TB, Giacomi PR, Loukas A, Mulvenna JP, Clark RJ, Miles JJ. Helminth Immunomodulation in Autoimmune Disease. Front Immunol. 2017; 8: 453.

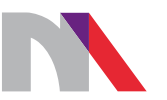

Ministry of Science and Higher Education

Republic of Poland

Generation of the DOI (Digital Object Identifier) - task financed under the agreement No. 618/P-DUN/2019 by the Minister of Science and Higher Education 